\title{
XII. A Chemical Analysis of Sodalite, a new Mineral from
}

Greenland. Bर Thomas Thomson, M.D. F.R.S. E. Fellow of the Imperial Chirurgo-Medical Academy of Petersburgh.

\section{[Read Nov. 5. 1810.]}

7 HE mineral to which I have given the name of Sodalite, I was alfo put into my hands by Mr Allan. In the Greenland collection which he purchafed, there were feveral fpecimens of a rock, obviounly primitive. In the compofition of thefe, the fubstance of which $I$ an about to treat, formed a conftituent, and, at firft appearance, was taken for felfpar, to which it bears a very ftriking refemblance.

Tuis rock is compofed of no lefs than five difierent foffils, namely, garnet, hornblende, augite, and two others, which form the pafte of the mafs. Thefe are evidently different minerals; but in fome fpecimens, are fo intimately blended, that it required the fkill of Count Bournon to make the difcrimination, and afcertain their real nature. Even this diftinguifhed mineralogift was at firft deceived by the external appect, and confidered the pafte as common lamellated felfpar, of a greenifh co1. our. But a peculiarity which prefented itfelf to Mr Allan, in one of the minerals, induced him to call the attention of Count Bournos more particularly to its conftaction.

ON a clofer examination of the mineral, $\mathrm{M}$. de Bourvos: found that fone fmall fragments, which he hid detached, pre- 
fented rectangular prifms, terminated by planes, meafuring, with the fides of the prifm, $110^{\circ}$ and $70^{\circ}$ or nearly $10,-a$ form which belongs to a rare mineral, known by the name of Sahlite, from Sweden. He further obferved, intermixed along with this, another material; and after fome trouble, fucceeded in detaching a mafs, prefenting a regular rhomboidal dodecahedron. It was to this form that Mr Allas had previoufly requefted his attention.

Some time before this inveftigation, M. de Bournon had examined a mineral from Sweden, of a lamellated ftructure, and a greenifh colour, which, he found, indicated the fame form. From this circumftance, together with fome external refemblance, which ftruck him, he was induced to conclude, that our mineral was a variety of that fubftance.

To that fubftance the name of Swedinh natrolite had been given, in confequence of the inveftigation of Dr Wollaston, who found that it contained a large proportion of foda.

ThERE are few minerals, however, that are fo totally diftinct in their external characters as the natrolite of KLAPROTH, and the fubftance we are now treating of. The mineral examined by KLAPROTH occurs at Roegan*, on the Lake of Conftance, in porphyry-flate, coating the fides of veins and cavities in a mamellated form, the texture of which is compact, fibrous, and radiated; the colour pale yellow, in fome places pafling into white, and marked with brown zones. Hitherto it had never been found in a ftate fufficiently perfect to afford any indications of form. Lately, however, M. de BouRnon was fo fortunate as to procure fome of it, prefenting very delicate needleform cryftals, which, by means of a ftrong magnifier, he was able to afcertain, prefented flat rectangular prifms, terminated by planes, which, he thought, might form angles of $60^{\circ}$

It has becn obferved allo by Profefor JAmeson, in the flotz-trap rock: behivit Burntifland, 
$60^{\circ}$ and 120 with the fides of the prifm. With this, neither our mineral nor the Swedifh can have any connection, farther than fome analogy which may exift in their compofition.

CONCERNING the Swedifh mineral, I have not been able to obtain much fatisfactory information. There is a fpecimen of it in $\mathrm{Mr}$ Allan's cabinet, which he received directly from Sweden, fent by a gentleman who had juft before been in London, and was well acquainted with the collections of that city, from which it is inferred, that the fpecimen in queftion is the fame as that examined by Count BouRNoN arid Dr WoLla.STON.

WERNER has lately admitted into his fyftem a new mineral fpecies, which he diftinguifhes by the name of Fettstein. Of this I have feen two defcriptions; one by $\mathrm{H}_{\mathrm{u}} \mathrm{ux}$, in his Tableau Comparatif; publifhed laft year; and another by Count DUNIN Borkowski, publifhed in the 69 th volume of the Journal de Physique, and tranflated in Nicholson's Journal, (vol. 26. p. $3^{84}$ ). The fpecimen, called Swedish Natrolite, in Mr ALlan's poffeffion, agrees with thefe defcriptions in every particular, excepting that its fpecific gravity is a little higher. BorKOWSKI ftates the fpecific gravity of fettstein at 2.563 ; Haiiy at 2.61 $3^{8}$; while I found the fpecific gravity of Mr AlLaN's fpecimen to be 2.779 , and, when in finall fragments, to be as high as 2.790 . This very near agreement in the properties of the Swedifh natrolite, with the characters of the fettftein, leads me to fuppofe it the fubftance to which WERNER has given that name. This opinion is ftrengthened, by a fact mentioned

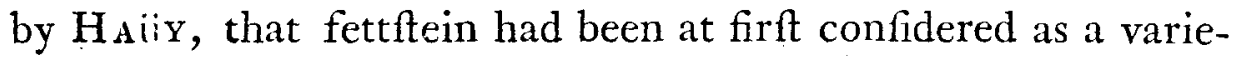
ty of Wernerite. For the fpecimen fent to Mr AlLaN, under the name of Compact Wernerite, is obvioufly the very fame with the fuppofed natrolite of Sweden. Now, if this identity be admitted, it will follow, that our mineral conftitutes a fpecies apart. It bears, indeed, a confiderable refemblance to it; but neither the cryftalline form, nor the conftituents of fettftein, 
as ftated by HAUY, are fimilar to thofe of the mineral to which I have given the name of Sodalite. The confituents of fettftein, as afcertained by VAUQUELIN, are as follows:

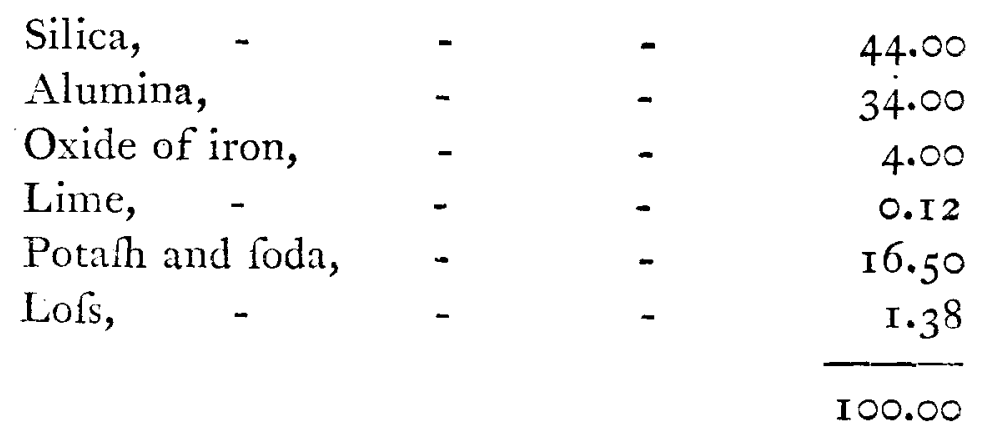

\section{DESCRIPTION OF SODALITE.}

SODALITE, as has been already mentioned, occurs in a primitive rock, mixed with fahlite, augite $*$, hornblende, and garnet $t$.

IT occurs maflive; and cryftallifed, in rhomboidal dodecahedrons, which, in fome cafes, are lengthened, forming fix-fided prifms, terminated by trihedral pyramids.

ITs colour is intermediate between celandine and mountain green, varying in intenfity in different fpecimens. In fome cales it feens intimately mixed with particles of fahlite, which doubtles modify the colour.

EXternat lufre glimmering, internal hining, in one direction vitrecus, in another refmous.

Fracture foliated, with at leaft a double cleavage; crofs fracture conchoidal.

Fr.GMEvis indeterminate; ufually tharp-edged.

TRANSLUCENT.

" Ths fituation of the atigite deferves attention. Fitherto it has been, with a few exception;, found only in fletz trap rocks.

1 The particular colour and appearance of this garnet, hews that the rock came from Greenland: For fimilar garnct has rever been oblerves, cxcept in fpecincus fion Greculand. 
TRANSLUCENT.

HARDNESs equal to that of felfpar. Iron foratches it with difficulty.

BRITTLE.

EAsILY frangible.

SPECIFIC gravity, at the temperature of $60^{\circ}, 2 \cdot 37^{\circ}$. The fpecimen was not abfolutely free from fahlite.

When heated to rednefs, does not decrepitate, nor fall to powder, but becomes dark-grey, and affumes very nearly the appearance of the Swedifh natrolite of Mr ALLAN, which I confider as fettftein. If any particles of fahlite be mixed with it, they become very confpicuous, by acquiring a white colour, and the opacity and appearance of chalk. The lofs of weight. was 2.I per cent. I was not able to melt it before the biowpipe.

\section{Chemical analysis.}

I. A HUNDRED grains of the mineral, reduced to a fine pow. der, were mixed with 200 grains of pure foda, and expofed for an hour to a ftrong red heat, in a platinum crucible. The mixture melted, and affumed, when cold, a beautiful grais-green colour. When foftened with water, the portion adhering to the fides of the crucible acquired a fine brownifh-yellow. Nitric acid being poured upon it, a complete folution was obtained.

2. Suspecting, from the appearance which the fufed mafs affumed, that it might contain chromim, I neutralifed the folution, as nearly as pollible, with ammonia, and then poured into it a recently prepared nitrate of mercury. A white precim pitate fell, which being dried, and expofed to a heat rather under rednefs, was all diflipated, except a inall portion of grey 
matter, not weighing quite o.I grain. This matter was infoluble in acids, but became white. With potafh it fufed into a colourlefs glafs. Hence I confider it as filica. This experiment thews that no chromium was prefent. I was at a lofs to account for the precipitate thrown down by the nitrate of mercury. But Mr Allan having thown me a letter from EkeBERG, in which he mentions, that he had detected muriatic acid in fodalite, it was eafy to fee that the whole precipitate was calomel. The white powder weighed 26 grains, indicating, according to the analyfis of CHENEvix, about 3 grains of muriatic acid.

3. THE folution, thus freed from muriatic acid, being concentrated by evaporation, gelatinifed. It was evaporated nearly to drynefs; the dry mafs, digefted in hot water acidulated with nitric acid, and poured upon the filter. The powder retained upon the filter was wafhed, dried, and heated to rednefs. It weighed 37.2 grains, and was filica.

4. THE liquor which had paffed through the filter, was fuperfaturated with carbonate of potafh, and the copious white precipitate which fell, collected by the filter, and boiled while yet moift in potafh-ley. The buik diminifhed greatly, and the undiffolved portion affumed a black colour, owing to fome oxide of mercury with which it was contaminated.

5. THE potafh-ley being paffed through the filter, to free it from the undiffolved matter, was mixed with a fufficient quantity of fal-ammoniac. A copious white precipitate fell, which being collected, wafhed, dried, and heated to rednefs, weighed 27.7 grains. This powder being digefted in fulphuric acid, diflolved, except 0.22 grain of filica. Sulphate of potafh being .dded, and the folution fet afide, it yielded alum cryftals to the very laft drop. Hence the 27.48 grains of diffolved powder were almuna. 
6. THE black refidue which the potah-ley had not taken up, was diffolved in diluted fulphuric acid. The folution being evaporated to drynefs, and the refidue digefted in hot water, a white foft powder remained, which, heated to rednefs, weighed 3.6 grains, and was fulphate of lime, equivalent to about 2 grains of lime.

7. THE liquid from which the fulphate of lime was feparated, being exactly neutralifed by ammonia, fuccinate of ammonia was dropped in ; a brownith-red precipitate fell, which, being heated to rednefs in a covered crucible, weighed I grain, and was black oxide of iron.

8. The refidual liquor being now examined by different reagents, nothing farther could be precipitated from it.

9. The liquid (No. 4.) from which the alumina, lime, and iron had been feparated by carbonate of potath, being boiled for fome time, let fall a fmall quantity of yellow-coloured matter. This matter being digefted in diluted fulphuric acid, partly diffolved with effervefcence; but a portion remained undiffolved, weighing $\mathbf{I}$ grain. It was infoluble in acids, and with potalh melted into a colourlefs glafs. It was therefore filica. The fulphuric acid folution being evaporated to drynefs, left a refidue, which pofferfed the properties of fulphate of lime, and which weighed 1.2 grains, equivalent to about 0.7 grains of lime.

ro. THE conftituents obtained by the preceding analyfis being obvioully defective, it remained to examine whether the mineral, according to the conjecture of BouR Non, contained an alkali. For this purpofe, roo grains of it, reduced to a fine powder, and mixed with 500 grains of nitrate of barytes, were expofed for an hour to a red heat, in a porcelain crucible. The fufed mafs was foftened with water, and treated with muriatic acid. The whole diffolved, except 25 grains of a white powVoL. VI. P. II. 
der, which proved on examination to be filica. The muriatic acid folution was mixed with fulphuric acid, evaporated to drynefs; the refidue, digefted in hot water, and filtered, to feparate the fulphate of barytes. The liquid was now mixed with an excefs of carbonate of ammonia, boiled for an inftant or two, and then filtered, to feparate the earth and iron precipitated by the ammonia. The liquid was evaporated to drynefs, and the dry mafs obtained expofed to a red heat in a filver cru cible. The refidue was diffolved in water, and expofed in the open air to fpontaneous evaporation. The whole gradually thot into regular cryftals of fulphate of foda. This falt being expofed to a ftrong red heat, weighed $5 \circ$ grains, indicating, according to BERTHOLLET's late analyfis, 23.5 grains of pure foda. It deferves to be mentioned, that during this procefs, the filver crucible was acted on, and a fmall portion of it was afterwards found among the fulphate of foda. This portion was feparated before the fulphate of foda was weighed.

THE preceding analyfis gives us the conftituents of fodalite as follows :

$\begin{array}{lllr}\text { Silica, - } & - & - & 38.5^{2} \\ \text { Alumina, } & - & - & 27.48 \\ \text { Lime, - } & - & - & 2.70 \\ \text { Oxide of iron, } & - & - & 1.00 \\ \text { Soda, - } & - & - & 23.5^{\circ} \\ \text { Muriatic acid, } & - & - & 3.00 \\ \text { Volatile matter, } & - & - & 2.10 \\ \text { Lofs, - } & - & - & 1.70 \\ & & & 100.00\end{array}$


Mr Aldan fent a fpecimen of this mineral to Mr EkeBERG, who analifed it in the courfe of laft fummer. The conftituents which he obtained, as he ftates them in a letter to $\mathrm{Mr}$ ALLAN, are as follows :

\begin{tabular}{|c|c|c|c|c|}
\hline Silica, & - & - & - & $3^{6}$ \\
\hline Alumina, & - & - & - & 32. \\
\hline Soda, & - & - & - & 25. \\
\hline Muriatic acid, & & - & - & 6.75 \\
\hline Oxide of iron, & & - & - & 0.25 \\
\hline
\end{tabular}

'THIs refult does not differ much from mine. The quantity of muriatic acid is much greater than mine. The lime and the volatile matter which I obtained, efcaped his notice altogether. If we were to add them to the alumina, it would make the two analyfes almoft the fame. No mineral has hitherto been found containing nearly fo much soda as this. Hence the reafon of the name by which I have diftinguithed it. 